Tersedia online di: http://ejournal-balitbang.kkp.go.id/index.php/jra

\title{
EFEKTIVITAS SALINITAS AIR DALAM MENINGKATKAN SINTASAN BELUT MONOPTERUS ALBUS DAN PENGARUHNYA TERHADAP PROFITABILITAS PENJUALAN BELUT HIDUP
}

\author{
lis Diatin", Yani Hadiroseyani, dan Danfi Astuti \\ Departemen Budidaya Perairan, Fakultas Perikanan dan IImu Kelautan, Institut Pertanian Bogor \\ Jalan Raya Darmaga, Kampus IPB Darmaga, Bogor 16680
}

(Naskah diterima: 24 Juni 2019; Revisi final: 7 Oktober 2019; Disetujui publikasi: 8 Oktober 2019)

\begin{abstract}
ABSTRAK
Belut (Monopterus albus) merupakan ikan air tawar konsumsi hasil tangkapan dari perairan umum yang dijual dalam keadaan hidup dengan harga tinggi dan permintaan yang terus meningkat. Aktivitas penangkapan, transportasi, dan penampungan menimbulkan kematian yang cukup banyak sehingga mengurangi stok dan nilai penerimaan penjualan belut. Penanganan belut pasca-penangkapan dalam air salin dapat menekan tingkat kematian belut, namun dampaknya terhadap keuntungan bisnis belum diketahui. Penelitian ini bertujuan untuk mengevaluasi penampungan dalam air salin terhadap sintasan dan keuntungan usaha penjualan belut hidup. Penelitian dilakukan pada pedagang besar belut hidup di Jawa Tengah yang memperoleh pasokan belut dari berbagai lokasi di Jawa. Belut uji yang diperoleh dari tiga lokasi yaitu Ciamis, Jawa Barat; Cilacap, Jawa Tengah; dan Lumajang, Jawa Timur; masing-masing ditampung terpisah dan dipelihara selama enam hari dalam air tawar (salinitas $0 \mathrm{~g} / \mathrm{L}$ ) dan air tawar yang ditambah garam krosok pada konsentrasi $6 \mathrm{~g} / \mathrm{L}$. Hasil menunjukkan bahwa penampungan selama seminggu dalam salinitas $6 \mathrm{~g} / \mathrm{L}$ menghasilkan tingkat sintasan belut 1,6 kali dibandingkan dengan penampungan dalam air tawar pada semua lokasi asal belut. Sintasan yang lebih tinggi tersebut meningkatkan nilai penerimaan dan keuntungan usaha.
\end{abstract}

KATA KUNCl: belut; sintasan; keuntungan; salinitas

ABSTRACT: The effects of different salinity levels in temporary containment systems on the survival rate of live Asian swamp eel (Monopterus albus) and its business profitability. By: lis Diatin, Yani Hadiroseyani, and Danfi Astuti

Asian swamp eel (Monopterus albus) is a highly-priced freshwater fish collected from natural waters and sold alive in the market with an ever-increasing demand. Fishing methods, transportation, and holding of live eels before being sold frequently result in significant mortality, which eventually reduces the sales revenue from the business. However, postcapture handling of the eel using saline water could reduce the mortality rate, but the impact on business profits has never been determined. This study was aimed to determine the effects of water salinity on the survival of the eels during the holding period and calculate the profit gain from live eel sales. The research was carried out in the facility of a wholesaler of live Asian swamp eel in Central Java which received eel supply from various locations in Java. The samples of eels were originated from three locations, namely Ciamis, West Java; Cilacap, Central Java; and Lumajang, East Java. The eels were placed in separate containers filled with: fresh water (salinity $0 \mathrm{~g} / \mathrm{L}$ ) and freshwater added with salt at concentration $6 \mathrm{~g} / \mathrm{L}$ for six days. The results showed that six days holding period in salinity of $6 \mathrm{~g} / \mathrm{L}$ resulted in a higher survival rate of the eels up to 1.6 times compared to the freshwater. This higher survival has increased the revenues and profitability of the live eels sales.

\section{KEYWORDS: Asian swamp eel; survival rate; profitability; salinity}

\footnotetext{
\# Korespondensi: Fakultas Perikanan dan IImu Kelautan, Institut

Pertanian Bogor. JI. Raya Darmaga, Kampus IPB Darmaga,

Bogor 16680, Indonesia.

Tel. + 622518622909

E-mail: iisdiatin@yahoo.co.id
} 


\section{PENDAHULUAN}

Salah satu komoditas perikanan yang memiliki nilai ekonomi tinggi adalah ikan belut (Monopterus albus, Zuiew 1793). Belut dijadikan bahan pangan oleh etnis Asia (Affandi et al., 2003; Nico et al., 2011). Ikan belut menjadi komoditas ikan paling penting pada masyarakat Tiongkok (Liang et al., 2016), sehingga selain untuk memenuhi pasar lokal, ikan belut ini memiliki potensi untuk ekspor. Tujuan ekspor perikanan Indonesia terutama adalah ke Tiongkok dengan pangsa mencapai $14 \%$ (IEl, 2019). Volume ekspor belut tahun 2017 mencapai 7.731 ton dengan nilai mencapai 15 juta USD (BPS, 2018). Permintaan belut yang terus meningkat tetapi tidak bisa diimbangi oleh produksi belut di Indonesia menyebabkan harga belut hidup cukup tinggi dan saat ini mencapai Rp70 $000,00 / \mathrm{kg}$. Produksi belut menghadapi tantangan penurunan populasi karena sebagian besar pasokan belut di pasar konsumsi masih berasal dari hasil tangkapan dari perairan umum (Affandi et al., 2003; Liang et al., 2016).

Tahapan penyediaan stok belut hidup untuk dijual, dimulai dari kegiatan penangkapan, transportasi, dan penampungan. Pada tahapan transportasi dan penampungan banyak terjadi kematian, yang disebabkan perubahan lingkungan hidup belut dan cara penangkapan. Metode penangkapan belut menggunakan alat setrum, dan pengumpulan belut hasil tangkapan pada wadah penampungan dengan media air tanpa lumpur menyebabkan ikan stres dan mengalami kematian (Hadiroseyani, 2016). Masalah pemeliharaan pasca-penangkapan yang menyebabkan stres juga terdapat pada ikan roach dan ikan bream (Martemyanov, 2013). Pengaruh stres pada ikan di antaranya dapat menganggu pertumbuhan, perkembangan fisiologis, reproduksi, resistensi terhadap penyakit menekan kemampuan imunitas, dan menyebabkan kematian (Schreck \& Tort, 2016).

Perusahaan yang memelihara dan menampung belut di antaranya adalah PT Cita Rasa di Yogyakarta. Peran perusahaan penampung sangat penting dalam rantai pasok kegiatan budidaya ikan, agar produknya sampai ke konsumen secara efisien dan berperan dalam menentukan harga di tingkat konsumen (Pham et al., 2018); serta menjadi rantai untuk mendukung pasokan di pasar dan sektor usaha komersial lainnya (Kaminski et al., 2018). Rantai pasok menjadi kunci keberhasilan pengembangan akuakultur (Asche et al., 2018); karena rantai pasok dapat meningkatkan hubungan pemasaran produk dari pembudidaya ke konsumen, serta dapat meningkatkan kapasitas produksi pembudidaya (Murshad-e-Jahan et al., 2018). Lembaga pemasaran juga penting untuk mengurangi kekosongan pasokan sehingga harga di tingkat konsumen relatif stabil (Pham et al., 2018).

Sumber belut yang diperoleh PT Cita Rasa berasal dari Jawa Timur, Jawa Tengah, dan Jawa Barat. Selama ini perusahaan tersebut memelihara dan menampung belut menggunakan media air tawar dan mengalami tingkat kematian yang tinggi mencapai 50\% Permasalahan utama pemeliharaan belut menggunakan air tawar adalah tingginya tingkat kematian yang disebabkan karena perubahan lingkungan. Belut umumnya ditemukan hidup pada lubang di areal persawahan dan kesulitan mengatasi stres akibat perubahan lingkungan (Hadiroseyani, 2016). Upaya yang dilakukan untuk meningkatkan sintasan belut adalah penambahan kadar garam pada air tawar sebanyak 6-9 g/L (Herwanti, 2017); hal ini dimungkinkan karena belut memiliki toleransi terhadap kadar garam dengan konsentrasi 0-16 g/L (Schofield \& Nico, 2009). Penggunaan kadar garam 6 $\mathrm{g} / \mathrm{L}$ sangat efektif dengan tingkat keberhasilan di atas 90\% dalam masa pemeliharaan 60 hari (Herwanti, 2017).

Tingkat kematian yang tinggi pada usaha ini menyebabkan kerugian yang cukup tinggi. Sehingga perlu upaya untuk mengurangi tingkat kematian tersebut dengan menambah garam pada media air. Oleh karena itu, pada penelitian ini dikaji efektivitas penambahan garam dalam pemeliharaan belut terhadap sintasan belut dan potensi peningkatan penerimaan, serta keuntungan penjualan belut hidup.

\section{BAHAN DAN METODE}

\section{Ikan Uji}

Belut yang digunakan dalam penelitian ini berasal dari Ciamis (Jawa Barat) dengan bobot (BW) dan panjang (TL) rata-rata sebesar $28,9 \pm 1,7 \mathrm{~g}$ dan 32,5 \pm 1,2 cm; Cilacap (Jawa Tengah) BW 27,6 \pm 1,7 g; TL $31,7 \pm 1,3 \mathrm{~cm}$; dan Lumajang (Jawa Timur) BW 29,6 $\pm 1,9 \mathrm{~g} ; \mathrm{TL} 32,5 \pm 1,2 \mathrm{~cm}$.

\section{Rancangan Percobaan}

Penelitian ini menggunakan rancangan acak faktorial (RAF), dengan dua faktor salinitas ( $0 \mathrm{~g} / \mathrm{L}$ dan $6 \mathrm{~g} / \mathrm{L}$ ) dan tiga faktor lokasi sumber belut (Lumajang, Cilacap, dan Ciamis) dengan pengulangan tiga kali setiap perlakuan.

\section{Pemeliharaan Belut}

Lokasi penelitian dilakukan di PT Cita Rasa di Yogyakarta. Pemeliharaan dilakukan pada dua tingkat salinitas yaitu air tawar (salinitas $0 \mathrm{~g} / \mathrm{L}$ ) dan air tawar yang ditambah garam krosok sebanyak $6 \mathrm{~g} / \mathrm{L}$ (salinitas 
$6 \mathrm{~g} / \mathrm{L}$ atau $6 \mathrm{ppt})$. Wadah yang digunakan pada penelitian ini berupa bak plastik persegi panjang berukuran 100 $\mathrm{cm} \times 80 \mathrm{~cm} \times 75 \mathrm{~cm}$, sebanyak 18 wadah yang masingmasing diisi air $80 \mathrm{~L}$. Belut dipelihara terpisah selama enam hari dengan padat penebaran per wadah 80 ekor (padat tebar 1 ekor/L). Pergantian air dilakukan sebanyak $100 \%$ setiap hari pada pukul 06.00 WIB. Stok air tawar dan air bergaram untuk pergantian air masing-masing ditampung pada tandon berukuran 720 L. Selama pemeliharaan belut tidak diberi pakan sesuai kebiasaan yang berlaku di perusahaan karena ikan terjual dalam waktu yang tidak lama. Kematian belut dihitung ketika dilakukan pergantian air.

\section{Parameter Uji dan Analisis Data}

Parameter uji terdiri atas parameter teknis untuk menganalisis efektivitas penggunaan garam dan parameter ekonomis untuk menganalisis profitabilitas usaha. Parameter teknis meliputi: sintasan (SR), faktor kondisi (FK), koefisien keragaman bobot (KKB), dan biomassa. Sintasan $(\mathrm{KH})$ dihitung menggunakan rumus Effendie (1997) yaitu:

$$
\mathrm{SR}=\frac{\mathrm{N}_{\mathrm{t}}}{\mathrm{N}_{0}} \times 100
$$

di mana: $N_{t}=$ jumlah ikan (ekor) pada akhir pemeliharaan $\mathrm{N}_{0}=$ jumlah ikan (ekor) pada awal pemeliharaan

Faktor kondisi (FK) dihitung dari bobot dan panjang ikan dengan rumus Fulton (Nash et al., 2006) sebagai berikut:

$$
F K=\frac{W}{L^{3}} \times 100
$$

di mana: $W=$ bobotikan $(\mathrm{g})$

$$
\mathrm{L}=\text { panjangikan }(\mathrm{cm})
$$

Koefisien keragaman (KK) digunakan untuk melihat perbandingan keragaman dua populasi atau lebih dan dihitung menggunakan rumus Steel \& Torrie (1981):

$$
K K=\frac{S}{Y} \times 100
$$

di mana: $\mathbf{S}=$ standar deviasi

$\mathrm{Y}=$ rerata populasi

Biomassa belut dihitung dengan menimbang seluruh ikan per wadah menggunakan alat timbangan dengan ketelitian 0,001 g.

Parameter profitabilitas terdiri atas analisis anggaran parsial dan analisis usaha. Analisis anggaran parsial mengacu pada Soekartawi et al. (1986), yaitu anggaran yang disusun secara tidak lengkap atau hanya menyusun sebagian anggaran tertentu saja. Analisis usaha dihitung berdasarkan parameter (Nurmalina et al., 2010):

1) biaya operasional= jumlah biaya tetap dan biaya variabel yang dikeluarkan dalam satu tahun produksi;

2) penerimaan per tahun= jumlah biaya yang dihasilkan selama satu tahun total produksi;

3) keuntungan = selisih antara penerimaan dan total biaya produksi;

4) Rasio $R / C=\frac{\text { Penerimaan }}{\text { Biaya Operasional }}$

Analisis profitabilitas menggunakan asumsi penjualan belut selama satu tahun (48 siklus) sebagai berikut:

1. Harga beli belut Rp33 000,00/kg dan harga jual belut Rp55 000,00/kg

2. Jumlah penampungan belut per siklus $135 \mathrm{~kg}$ dan setahun $6.500 \mathrm{~kg}$

Parameter uji ditabulasi menggunakan Microsoft Excel 2007, kemudian dianalisis menggunakan analisis sidik ragam (ANOVA) dua arah. Uji lanjut dilakukan dengan Uji Tukey pada selang kepercayaan 95\%

\section{HASIL DAN BAHASAN}

\section{Analisis Penggunaan Garam}

Penampungan belut selama enam hari dalam air tawar salinitas $0 \mathrm{~g} / \mathrm{L}$ dan $6 \mathrm{~g} / \mathrm{L}$ menghasilkan kinerja yang berbeda (Tabel 1). Lokasi merupakan faktor yang dapat memengaruhi SR dan FK belut. Belut Lumajang menunjukkan FK dan SR yang lebih baik dibandingkan dengan belut Ciamis dan Cilacap. Kadar garam merupakan faktor yang dapat memengaruhi SR, KKB, dan FK belut. Penampungan dalam salinitas $6 \mathrm{~g} / \mathrm{L}$ menghasilkan SR dan FK yang lebih baik dibandingkan dengan penampungan dalam salinitas $0 \mathrm{~g} / \mathrm{L}$ dan berlaku pada masing-masing lokasi. Tingkat sintasan belut pada perlakuan $0 \mathrm{~g} / \mathrm{L}$ untuk lokasi Lumajang, Cilacap, dan Ciamis masing-masing sebesar 53\% 49\% dan 50\% dan perlakuan $6 \mathrm{~g} / \mathrm{L}$ untuk lokasi Lumajang, Cilacap dan Ciamis masing-masing sebesar $89 \% 82 \%$ dan $84 \%$ Sintasan belut dalam salinitas $6 \mathrm{~g} / \mathrm{L}$ meningkat 1,6 kali lipat dibandingkan dalam salinitas $0 \mathrm{~g} / \mathrm{L}$. Penambahan garam pada media pemeliharaan belut dapat menekan kematian karena belut mengalami gradien osmotik yang cukup tinggi pada media air tawar (Hadiroseyani, 2016) dan mengakibatkan belut mengalami sodium linkage sehingga kehilangan banyak garam tubuh (Wedemeyer, 1996). Nilai KKB pada salinitas $6 \mathrm{~g} / \mathrm{L}$ bertambah lebar dalam enam hari masa penampungan, menunjukkan telah terjadi respons 
Tabel 1. Faktor kondisi, koefisien keragaman bobot dan sintasan belut (Monopterus albus) asal Lumajang, Cilacap, dan Ciamis pada pemeliharaan dengan salinitas $0 \mathrm{~g} / \mathrm{L}$ dan $6 \mathrm{~g} / \mathrm{L}$

Table 1. The effect of temporary containment system at salinity $0 \mathrm{~g} / \mathrm{L}$ and $6 \mathrm{~g} / \mathrm{L}$ on condition factor, diversity weight coefficient, and survival rate of Asian swamp eel

\begin{tabular}{|c|c|c|c|c|}
\hline $\begin{array}{l}\text { Lokasi } \\
\text { Location }\end{array}$ & $\begin{array}{l}\text { Salinitas } \\
\text { Salinity (g/L) }\end{array}$ & $\begin{array}{c}\text { FK } \\
\text { CF (\%) }\end{array}$ & $\begin{array}{c}\text { KKB } \\
\text { DWC }(\%)\end{array}$ & $\begin{array}{c}\text { Sintasan } \\
\text { Survival rate }(\%)\end{array}$ \\
\hline \multirow{2}{*}{ Lumajang } & 0 & $0.05 \pm 0.001^{\mathrm{aba}}$ & $18.52 \pm 0.70^{\mathrm{aba}}$ & $53.40 \pm 2.73^{\mathrm{aba}}$ \\
\hline & 6 & $0.05 \pm 0.001^{\text {aaa }}$ & $23.27 \pm 1.87^{\text {aaa }}$ & $88.56 \pm 2.03^{\text {aaa }}$ \\
\hline \multirow{2}{*}{ Cilacap } & 0 & $0.03 \pm 0.001^{\mathrm{bba}}$ & $18.52 \pm 0.50^{\mathrm{aba}}$ & $48.87 \pm 1.25^{\mathrm{bba}}$ \\
\hline & 6 & $0.04 \pm 0.001^{\text {baa }}$ & $22.13 \pm 1.30^{\text {aаa }}$ & $82.23 \pm 2.03^{\text {baa }}$ \\
\hline \multirow{2}{*}{ Ciamis } & 0 & $0.03 \pm 0.001^{\mathrm{bba}}$ & $18.52 \pm 0.70^{\mathrm{aba}}$ & $50.10 \pm 1.08^{\mathrm{bba}}$ \\
\hline & 6 & $0.04 \pm 0.001^{\text {baa }}$ & $23.27 \pm 1.87^{\text {aаa }}$ & $84.01 \pm 2.75^{\text {baa }}$ \\
\hline
\end{tabular}

\begin{tabular}{llll}
\hline ANOVA dua arah (nilai P) & & & \\
Two way ANOVA (P value) & & & \\
Lokasi (Location) & 0.000 & 0.141 & 0.001 \\
Salinitas (Salinity) & 0.014 & 0.000 & 0.000 \\
Lokasi * salinitas (Location * salinity) & 0.473 & 0.206 & 0.641 \\
\hline
\end{tabular}

Keterangan: Huruf superskrip yang berbeda pada kolom yang sama menunjukkan pengaruh perlakuan yang berbeda nyata $(P<0,05)$. Huruf pertama merupakan faktor lokasi, huruf kedua merupakan faktor salinitas, dan huruf ketiga merupakan interaksi antara faktor lokasi dan faktor sal initas

Remarks: Different superscript letters in the same column show significantly different treatment effects $(P<0.05)$. The first letter is a location factor, the second letter is a salinity factor, and the third letter is an interaction between a location factor and salinity factor

individu belut yang berbeda akibat perlakuan dalam penampungan. Sementara itu, pada salinitas $0 \mathrm{~g} / \mathrm{L} \mathrm{KKB}$ sama untuk setiap asal lokasi belut. Tidak terdapat interaksi antara faktor lokasi dan salinitas.

Daya tampung aktual di PT Citra Rasa sejumlah $6.500 \mathrm{~kg}$ belut per tahun. Tabel 2 menampilkan potensi total penyusutan biomassa belut pada salinitas $0 \mathrm{~g} / \mathrm{L}$ dan $6 \mathrm{~g} / \mathrm{L}$ berdasarkan nilai SR selama enam hari penampungan. Nilai penyusutan biomassa belut pada salinitas $0 \mathrm{~g} / \mathrm{L}$ berkisar $47 \% 51 \%$ sedangkan pada salinitas $6 \mathrm{~g} / \mathrm{L}$ hanya berkisar 12\%18\% Peningkatan salinitas dapat menekan nilai penyusutan biomassa belut akibat penampungan, dan berlaku pada semua asal lokasi belut. Pada umumnya ikan air tawar bersifat hiperosmotik terhadap lingkungannya. Kadar garam plasma belut pada air dengan salinitas 0-5 g/L adalah berkisar $150 \mathrm{mmol} / \mathrm{L}$ (Pedersen et al., 2014). Adapun nilai osmolalitas belut dalam air tawar pada kisaran $268 \pm 16$ (Hadiroseyani, 2016); $274 \pm 5$ (Pedersen et al., 2014); dan $299 \pm 4 \mathrm{mOsm} / \mathrm{kg}$ (Tok et al., 2009); sehingga belut mengalami gradien osmotik yang cukup tinggi terhadap air tawar dan mengakibatkan belut mengalami sodium leakage sehingga kehilangan banyak garam tubuh. Berdasarkan penelitian Herwanti (2017) populasi belut yang dipelihara pada salinitas $0 \mathrm{~g} / \mathrm{L}$ mengalami kematian 100\%dalam 14 hari pertama masa pemeliharaan sedangkan pada salinitas $6 \mathrm{~g} / \mathrm{L}$ tingkat kematian sangat rendah yaitu sekitar $7 \%$ dalam dua bulan pemeliharaan. Tampak jelas bahwa kadar garam lingkungan sangat memengaruhi tingkat sintasan belut. Kehilangan garam tubuh pada belut dapat terjadi sejak aktivitas penangkapan (Hadiroseyani, 2016). Pada umumnya belut ditangkap menggunakan alat setrum, pancing, dan bubu; kemudian ditampung dalam bak berisi air tawar pada kepadatan yang sangat tinggi. Belut yang memiliki nilai SR tertinggi adalah belut yang berasal dari Lumajang (Jawa Timur). Hal ini diduga karena berdasarkan hasil wawancara, petani di Lumajang (Jawa Timur) masih melakukan pengembalian jerami ke sawah. Pengembalian jerami menyebabkan kandungan C-organik yang ada di tanah akan selalu tersedia. Penggunaan bahan organik berupa kompos dari jerami padi maupun pupuk kandang sangat besar peranannya dalam meningkatkan kesuburan tanah. Habitat yang disukai belut sawah adalah sawah yang cukup akan air dan kaya akan bahan organik (Shafland et al., 2010), diduga kondisi inilah yang menyebabkan sumber belut dari lumajang lebih bugar.

Pada awal kedatangan stok, FK belut adalah 0,084\% $0,087 \%$ dan pada hari keenam turun menjadi $0,03 \%$ 0,04\% pada salinitas $0 \mathrm{~g} / \mathrm{L}$ dan $0,04 \% 0,05 \%$ pada 
salinitas $6 \mathrm{~g} / \mathrm{L}$, yang menunjukkan belut semakin kurus pada semua perlakuan dan belut yang kurus dapat mengurangi biomassa penjualan. Menurut Hadiroseyani (2016), nilai FK belut selama pemberokan tiga hari pada salinitas $6 \mathrm{~g} / \mathrm{L}$ mencapai 9\% Penurunan nilai FK dapat disebabkan faktor-faktor pemicu stres pada kegiatan pemeliharaan belut, di antaranya perubahan lingkungan, peningkatan kepadatan, dan tidak ada sumber makanan. Menurut Dennis \& Bulger (1995), penyebab FK menurun berkaitan dengan konsentrasi sodium dan regulasi ion, seperti yang terjadi pada ikan blacknose dace (Rhinichthys atratulus).

Biomassa merupakan bobot total ikan yang dapat dijual untuk meenghasilkan keuntungan usaha. Selama penampungan telah terjadi penurunan biomassa belut, dengan nilai yang terkecil terdapat pada belut yang berasal dari Lumajang (Jawa Timur). Penurunan biomassa belut dapat dilihat pada Tabel 2 .

Biomassa merupakan bobot total belut yang dapat dijual untuk meenghasilkan keuntungan usaha. Penurunan biomassa belut yang terkecil adalah pada belut yang berasal dari Lumajang (Jawa Timur) yaitu $47 \%$ pada salinitas $0 \mathrm{~g} / \mathrm{L}$ dan $12 \%$ ada salinitas $6 \mathrm{~g} / \mathrm{L}$. Penggunaan salinitas $6 \mathrm{~g} / \mathrm{L}$ mampu mempertahankan stok belut penjualan yang lebih banyak dibandingkan salinitas $0 \mathrm{~g} / \mathrm{L}$. Walaupun tidak ada pemberian pakan selama penampungan, pada salinitas $6 \mathrm{~g} / \mathrm{L}$ penurunan biomassa tidak sebanyak pada salinitas $0 \mathrm{~g} / \mathrm{L}$, hal ini disebabkan karena tekanan osmotik antara lingkungan dan tubuh belut hampir sama sehingga pemanfaatan cadangan energi untuk osmoregulasi lebih sedikit. Sejalan dengan hasil penelitian Mattioli et al. (2017) yang menunjukkan bahwa salinitas dapat meningkatkan kinerja produksi ikan lele. Faktor yang menjadi penentu bagi pembudidaya dalam mengadopsi suatu teknologi adalah tingkat produktivitas dan biaya produksi. Makin tinggi tingkat produktivitas maka peluang adopsi teknologi makin besar, sementara makin tinggi biaya produksi menyebabkan peluang adopsi teknologi makin rendah. Menurut Chand \& Kaul (1986), dalam suatu proses produksi, skala usaha menggambarkan respons dari keluaran terhadap perubahan proporsional. Dengan mengetahui kondisi skala usaha, pengusaha dapat mempertimbangkan perlu tidaknya suatu usaha dapat dikembangkan lebih lanjut. Oleh karena itu, penggunaan garam pada pemeliharaan belut dapat direkomendasikan.

\section{Analisis Profitabilitas}

Pada perhitungan analisis anggaran parsial, terdapat biaya tambahan pada pemeliharaan belut yang menggunakan garam (salinitas $6 \mathrm{~g} / \mathrm{L}$ ) berupa biaya pembelian garam, transportasi garam, dan penyusutan alat salinometer. Perhitungan analisis anggaran parsial disajikan pada Tabel 3.

Kegiatan pemeliharaan belut pada salinitas $0 \mathrm{~g} / \mathrm{L}$ menghasilkan penerimaan sebesar Rp189.475.000,00 untuk Lumajang; Rp175.175.000,00 untuk Cilacap; dan Rp178.750.000,00 untuk Ciamis. Penggunaan media pemeliharaan belut pada salinitas $6 \mathrm{~g} / \mathrm{L}$ memerlukan biaya tambahan sebesar Rp2.793.700,00 untuk pembelian garam, transportasi pembelian garam, dan penyusutan salinometer. Namun penggunaan garam ini dapat meningkatkan penerimaan tambahan pada usaha ini dan menghasilkan penerimaan tambahan untuk sumber belut dari Lumajang, Cilacap, dan Ciamis masing-masing sebesar sebesar Rp125.906.300,00; Rp115.181.300,00; dan Rp118.756.000,00. Pemeliharaan belut pada salinitas $6 \mathrm{~g} / \mathrm{L}$ meningkatkan penerimaan mencapai 68\%dibandingkan pemeliharaan pada air tawar (salinitas $0 \mathrm{~g} / \mathrm{L}$ ). Sehingga pada kajian ini selanjutnya dilakukan perhitungan analisis usaha pemeliharaan belut pada salinitas $6 \mathrm{~g} / \mathrm{L}$ yang disajikan pada Tabel 4.

Tabel 2. Penurunan biomassa belut (M onopterus albus) asal Lumajang, Cilacap, dan Ciamis pada pemeliharaan dengan salinitas $0 \mathrm{~g} / \mathrm{L}$ dan $6 \mathrm{~g} / \mathrm{L}$

Table 2. Decrease in biomass of Asian swamp eel (Monopterus albus) after temporary containment system at salinity $0 \mathrm{~g} / \mathrm{L}$ and $6 \mathrm{~g} / \mathrm{L}$

\begin{tabular}{lcccc}
\hline \multirow{2}{*}{$\begin{array}{c}\text { Parameter } \\
\text { Parameters }\end{array}$} & Salinitas & \multicolumn{3}{c}{ Lokasi (Location) } \\
\cline { 3 - 5 } & Salinity (g/L) & Lumajang & Cilacap & Ciamis \\
\hline Biomassa awal & 0 & 6,500 & 6,500 & 6,500 \\
Initial biomass $(\mathrm{kg})$ & 6 & 6,500 & 6,500 & 6,500 \\
\cline { 3 - 5 } $\begin{array}{l}\text { Biomassa akhir } \\
\text { Final biomass (kg) }\end{array}$ & 0 & 3,445 & 3,185 & 3,250 \\
Penyusutan biomassa & 6 & 5,720 & 5,330 & 5,460 \\
\hline Reduction biomass (\%) & 0 & 47.00 & 51.00 & 50.00 \\
\hline
\end{tabular}


Tabel 3. Analisis anggaran parsial usaha belut (Monopterus albus) pada salinitas $6 \mathrm{~g} / \mathrm{L}$

Table 3. Partial budget analysis on sales of Asian swamp eel (Monopterus albus) at salinity $6 \mathrm{~g} / \mathrm{L}$

\begin{tabular}{|c|c|c|c|c|}
\hline $\begin{array}{l}\text { Lokasi } \\
\text { Location }\end{array}$ & $\begin{array}{c}\text { Kerugian } \\
\text { Loss }\end{array}$ & $\begin{array}{c}\text { Jumlah (Rp) } \\
\text { Total (IDR) }\end{array}$ & $\begin{array}{c}\text { Keuntungan } \\
\text { Profit }\end{array}$ & $\begin{array}{c}\text { Jumlah (Rp) } \\
\text { Total (IDR) }\end{array}$ \\
\hline Lumajang & $\begin{array}{l}\text { Biaya tambahan } \\
\text { Incremental cost } \\
\text { Penyusutan salinometer } \\
\text { Depreciation salinometer } \\
\text { Garam (Salt) } \\
\text { Transportasi garam } \\
\text { Salt transportation } \\
\text { Biaya tambahan total } \\
\text { Total incremental cost } \\
\text { Penerimaan (sintasan 53\% } \\
\text { Revenue (survival rate 53\%) } \\
\text { Penerimaan tambahan total } \\
\text { Total incremental revenue }\end{array}$ & $\begin{array}{r}280,000 \\
2,419,200 \\
94,500\end{array}$ & $\begin{array}{l}\text { Penerimaan (sintasan 89\%) } \\
\text { Revenue (survival rate 89\%) }\end{array}$ & $\begin{array}{l}318,175,000 \\
125,906,300\end{array}$ \\
\hline Cilacap & $\begin{array}{l}\text { Biaya tambahan } \\
\text { Incremental cost } \\
\text { Penyusutan salinometer } \\
\text { Depreciation salinometer } \\
\text { Garam (Salt) } \\
\text { Transportasi garam } \\
\text { Salt transportation } \\
\text { Biaya tambahan total } \\
\text { Total incremental cost } \\
\text { Penerimaan (sintasan 53\% } \\
\text { Revenue (survival rate 53\%) } \\
\text { Penerimaan tambahan total } \\
\text { Total incremental revenue }\end{array}$ & $\begin{array}{r}280,000 \\
2,419,200 \\
94,500 \\
2,793,700\end{array}$ & $\begin{array}{l}\text { Penerimaan (sintasan 82\%) } \\
\text { Revenue (survival rate } 82 \% \text { ) }\end{array}$ & $\begin{array}{l}293,150,000 \\
115,181,300\end{array}$ \\
\hline Ciamis & $\begin{array}{l}\text { Biaya tambahan } \\
\text { Incremental cost } \\
\text { Penyusutan salinometer } \\
\text { Depreciation salinometer } \\
\text { Garam (Salt) } \\
\text { Transportasi garam } \\
\text { Salt transportation } \\
\text { Biaya tambahan total } \\
\text { Total incremental cost } \\
\text { Penerimaan (sintasan 53\% } \\
\text { Revenue (survival rate 53\%) } \\
\text { Penerimaan tambahan total } \\
\text { Total incremental revenue }\end{array}$ & $\begin{array}{r}280,000 \\
2,419,200 \\
94,500 \\
2,793,700\end{array}$ & $\begin{array}{l}\text { - } \\
\text { Penerimaan (sintasan 84\%) } \\
\text { Revenue (survival rate 84\%) }\end{array}$ & $\begin{array}{l}300,300,000 \\
118,756,000\end{array}$ \\
\hline
\end{tabular}

Sumber belut yang berasal dari Lumajang memberikan keuntungan usaha tertinggi dibanding lokasi lainnya, namun nilai imbangan penerimaan dan biaya $(R / C)$ untuk ketiga lokasi hampir sama dan menunjukkan bahwa usaha penampungan ini menguntungkan. Nilai R/C 1,10 menunjukkan bahwa setiap biaya yang dikeluarkan sebesar Rp1,00 akan menghasilkan penerimaan sebesar Rp1,10. Beberapa penelitian sebelumnya pada beberapa ikan air tawar yakni pada ikan mas yang dipelihara dengan padat tebar rendah menghasilkan nilai $\mathrm{R} / \mathrm{C} 0,71$ dan jika padat tebar ditingkatkan dua kali, nilai R/C meningkat dua kali menjadi 2,76 (Mohammad et al., 2018); hal ini menunjukkan bahwa peningkatan jumlah produksi 
Tabel 4. Analisis usaha pemeliharaan belut (Monopterus albus) pada salinitas $6 \mathrm{~g} / \mathrm{L}$ selama satu tahun

Table 4. Business analysis of Asian swamp eel based on temporary containment system at salinity $6 \mathrm{~g} / \mathrm{L}$

\begin{tabular}{lccc}
\hline \multicolumn{1}{c}{ Lokasi } & \multicolumn{3}{c}{ Salinitas/Salinity (6 g/L) } \\
\cline { 2 - 4 } & Lumajang & Cilacap & Ciamis \\
\hline $\begin{array}{l}\text { Penerimaan total (Rp) } \\
\text { Total revenue (IDR) }\end{array}$ & $318,175,000$ & $293,150,000$ & $300,300,000$ \\
$\begin{array}{l}\text { Biaya investasi (Rp) } \\
\text { Investment (IDR) }\end{array}$ & $7,190,000$ & $7,190,000$ & $7,190,000$ \\
$\begin{array}{l}\text { Biaya tetap (Rp) } \\
\text { Fixed cost (IDR) }\end{array}$ & $48,889,850$ & $48,889,850$ & $48,889,850$ \\
$\begin{array}{l}\text { Biaya variabel (Rp) } \\
\text { Variable cost (IDR) } \\
\text { Biaya operasional (Rp) }\end{array}$ & $240,115,200$ & $220,915,200$ & $225,715,200$ \\
$\begin{array}{l}\text { Operational cost (IDR) } \\
\text { Keuntungan (Rp) }\end{array}$ & $289,005,050$ & $269,805,050$ & $274,605,050$ \\
$\begin{array}{l}\text { Profit (IDR) } \\
\text { Imbangan penerimaan dan biaya }\end{array}$ & $30,040,950$ & $23,215,950$ & $25,565,950$ \\
Revenue cost ratio (R/C) & 1.10 & 1.09 & 1.09 \\
\hline
\end{tabular}

dapat meningkatkan nilai R/C (Diatin et al., 2017). Usaha ikan nila menghasilkan nilai R/C 1,26 pada luas lahan kurang dari satu hektar dan R/C 1,33-1,37 untuk luas lahan lebih dari satu hektar (Yuan et al., 2017); serta R/C 1,2 pada skala urban (Asciuto et al., 2019); namun pada skala menengah menghasikan $\mathrm{R} / \mathrm{C}$ sebesar 3,21 (Diatin et al., 2007). Ikan nila yang dipelihara di hapa memperoleh nilai R/C 1,60; sedangkan yang dipelihara dalam rumah kaca dan rumah kaca berpemanas masing-masing sebesar 1,82 dan 1,40 (Nasr-Allah et al., 2014). Ikan lele dumbo menghasilkan R/C 1,23 (Rochman et al., 2014); ikan lele yang dipelihara polikutur dengan ikan nila menghasilkan R/ C 1,07 (Shoko et al., 2016); sedangkan ikan lele yang diberi pakan probiotik menghasilkan R/C 1,19 dan tanpa probiotik 1,15 (Dewi \& Tahapari, 2017). Pada ikan patin skala kecil menghasilkan R/C 1,37 (Ali et al., 2018); R/C 1,74 (Alam, 2011); dan R/C 1,05 (Alam et al., 2019). Kegiatan budidaya ikan di wilayah Oyo State, Nigeria menghasilkan R/C 1,69 (Olaoye et al., 2013); sedangkan di wilayah Ekiti, Nigeria menghasilkan rata-rata R/C 1,74 (Omobepade et al., 2015). Pada usaha penjualan ikan tingkat pengecer diperoleh nilai R/C 1,44 dan pada tingkat grosir 1,9 (Laskar et al., 2016). Berdasarkan hasil penelitian ini maka perlu diupayakan peningkatan nilai R/C dari usaha penampungan belut ini dengan cara meningkatkan volume penjualan, mengoptimalkan kepadatan stok belut dalam penampungan dan menghemat biaya transportasi pembelian belut.

\section{KESIMPULAN}

Penambahan garam sebanyak $6 \mathrm{~g} / \mathrm{L}$ pada air tawar yang digunakan untuk penampungan selama enam hari dapat menekan tingkat kematian sehingga menghasilkan sintasan belut yang lebih tinggi, serta meningkatkan penerimaan dan keuntungan usaha penampungan ikan belut.

\section{UCAPAN TERIMA KASIH}

Penulis menyampaikan terima kasih kepada PT Cita Rasa, Yogyakarta; sehingga penelitian ini dapat terlaksana.

\section{DAFTAR ACUAN}

Affandi, R., Ernawati Y., \& Wahyudi, S. (2003). Studi bio-ekologi ikan belut sawah Monopterus albus pada berbagai ketinggian tempat di Kabupaten Subang, Jawa Barat. Jurnal Iktiologi Indonesia, 3(2), 49-55.

Alam, M.P. (2011). Measuring technical, allocative and cost efficiency of pangas (Pangasius hypophthalmus: Sauvage 1878) fish farmers of Bangladesh. Aquaculture Research, 42, 1487-1500.

Alam, M.M., Haque, M.M., Aziz, M.S.B., \& Mondol, M.M.R. (2019). Development of pangasius-carp polyculture in Bangladesh: Understanding farm characteristic by, and association between, socioeconomic and biological variables. Aquaculture, $505,431-440$. 
Ali, H., Rahman, M.M., Jahan, K.M., \& Dhar, G.C. (2018). Production economics of striped catfish (Pangasianodon hypophthalmus, Sauvage, 1878) farming under polyculture system in Bangladesh. Aquaculture, 491, 381-390.

Asche, F., Cojocaru, A.L., \& Roth, B. (2018). The development of large scale aquaculture production: A comparison of the supply chains for chicken and salmon. Aquaculture, 493, 446-455.

Asciuto, A., Schimmenti. E., Cottone, C., \& Borsellino, V. (2019). A financial feasibility studi of an aquaponic system in a Meditteranean urban context. Urban Forestry and Urban Greening, 38, 397-402.

Badan Pusat Statistik [BPS]. (2018). Indikator pertanian 2017. Badan Pusat Statistik. Jakarta, $170 \mathrm{hlm}$.

Chand, R. \& Kaul, J.L. (1986). A note on the use of the cobb-douglas profit function. American Journal of Agricultural Economics, 68(1), 162-164.

Dennis, T.E. \& Bulger, A.J. (1995). Condition factor and whole-body sodium concentrations in a freshwater fish: Evidence for acidification stress and possible ionoregulatory over-compensation. Water, air, and soil pollution, 85(2), 377-382.

Diatin, I., Sobari, M.P., \& Irianni, R. (2007). Analisis kelayakan finansial budidaya ikan nila wanayasa pada kelompok pembudidaya Mekarsari. Jurnal Akuakultur Indonesia, 6(1), 97-102.

Diatin, I., Nuristy, D.F., Teduh, A., \& Mujahid, M. (2017). Incremental net benefits from the increasing in the production of koi fish Cyprinus carpio var. koi culture. Jurnal Akuakultur Indonesia, 16(1), 68-75.

Dewi, R.R.S.P.S. \& Tahapari, E. (2017). Pemanfaatan probiotik komersial pada pembesaran ikan lele (Clarias gariepinus). Jurnal Riset Akuakultur, 12(3), 275-281.

Effendie, M.I. (1997). Biologi perikanan. Yogyakarta: Yayasan Pustaka Nusatama, $163 \mathrm{hlm}$.

Hadiroseyani, Y. (2016). Peranan salinitas dalam meningkatkan kelangsungan hidup ikan belut (Monopterus albus) pada transportasi dan budidaya menggunakan media air. Disertasi. Institut Pertanian Bogor.

Herwanti, I. (2017). Kinerja produksi belut sawah (Monopterus albus) pada budidaya sistem resirkulasi dengan media air bersalinitas 0, 6, dan $9 \mathrm{~g} / \mathrm{L}$. Skripsi. Institut Pertanian Bogor.

Indonesia Eximbank Institute [IEI]. (2019). Proyeksi ekspor berdasarkan industri: Komoditas unggulan. Indonesia Eximbank. Jakarta, Indonesia, $281 \mathrm{hlm}$.

Kaminski, A.M., Genschick, S., Kefi, A.S., \& Kruijssen, F. (2018). Commercialization and upgrading in the aquaculture value chain in Zambia. Aquaculture, 493, 355-364.

Laskar, B., Saha, B., \& Sarkar, A. (2016). Marketing channel vis-à-vis economic viability of ornamental fish cum aquarium in Agartala, Tripura. Economic Affairs, 61(4), 697-705.

Liang, H., Guo, S., Li, Z., Luo, X., \& Zou, G. (2016). Assessment of genetic diversity and population structure of swamp eel Monopterus albus in China. Biochemical Systematics ang Ecology, 68, 81-87.

Martemyanov, V.I. (2013). Pattern of changes in sodium content in plasma and erythrocytes of freshwater fish at stress. Journal of Ichthyology, 53(3), 220-224.

Mattioli, C.C., Takata, R., Leme, F.O.P., Costa, D.C., Filho, R.M., Silva, W.S., \& Luz, R.K. (2017). The effects of acute and chronic exposure to water salinity on juveniles of the carnivorous freshwater catfish Lophiosilurus alexandri. Aquaculture, 481, 255-266.

Mohammad, T., Moulick, S., \& Mukherjee, C.K. (2018). Economic feasibility of goldfish (Carassius auratus Linn.) recirculating aquaculture system. Aquaculture Research, 45(9), 2945-2953.

Murshad-e-Jahan, K., Ali, H., Upraity, V., Gurung, S., Dhar, G.C., \& Belton, B. (2018). Making sense of the market: Assessing the participatory market chain approach to aquaculture value chain development in Nepal and Bangladesh. Aquaculture, 493, 395-405.

Nash, R.D.M., Valecia, A.H., \& Geffen, A.J. (2006). The origin of Fulton's condition factor-setting the record straight. Fisheries History, 31(5), 236-239.

Nasr-Allah, A.M., Dickson, M.W., Al-Kenawy, D.A.R., Ahmed, M.F.M., \& El-Naggar, G.O. (2014). Technical characteristics and economic performance of commercial tilapia hatcheries applying different management systems in Egypt. Aquaculture, 426427, 222-230.

Nico, L.G., Sharp, P., \& Collins, T.M. (2011). Imported Asian swamp eels (Synbranchidae: Monopterus) in North American live food markets: Potential vectors of non-native parasites. Aquatic Invasions, 6(1), 69-76.

Nurmalina, R., Sarianti, T., \& Karyadi, A. (2010). Studi kelayakan bisnis. Departemen Agribisnis FEM, Institut Pertanian Bogor. Bogor, $189 \mathrm{hlm}$.

Olaoye, O.J., Dejo, A., Fakoya, S.S., Ikeweinwe, E.O., Alegbeleye, W.O., Ashaolu, F.O., \& Adelaja, O.A. (2013). Assessment of socio-economic analysis of fish farming in Oyo State, Nigeria. Global Journal of ScienceFrontier Research Agriculture and Veterinary, 13(9), 1-12. 
Omobepade, B.P., Adebayo, O.T., Amos, T.T., \& Adedokun, B.C. (2015). Profitability analysis of aquaculture in Ekiti State, Nigeria. Nigerian Journal of Agriculture, Food and Environment, 11(1), 114-119.

Pedersen, P.B.M., Hansen, K., Huong, D.T.T., Bayley, M., \& Wang, T. (2014). Effects of salinity on osmoregulation, growth and survival in Asian swamp eel (Monopterus albus) (Zuiew 1793). Aquaculture Research, 45(3), 427-438.

Pham, T.A.N., Meuwissen, M.P.M., Le, T.C., \& Bosma, R.H. (2018). Price transmission along the Vietnamese pangasius export chain, Aquaculture, 493, 416-423.

Rochman, A., Hastuti, D., \& Endah, S. (2014). Analisis usaha budidaya ikan lele dumbo (Clarias gariepinus) di Desa Wonosari Kecamatan Bonang Kabupaten Demak. Jurnal IImu-ilmu Pertanian, 10(2), 57-68.

Schreck, C.B. \& Tort, L. (2016). The concept of stress in fish. In Schreck, C.B., Tort, L., Farrel A.P., \& Brauner, C.J. (Eds.). Biology of stress in fish. United Kingdom: Fish Physiology, Academic Press, p. 1-34.

Shafland, P.L., Gestring, K.B., \& Stanford, M.S. (2010). An assessment of the Asian swamp eel (M onopterus albus) in Florida. Reviews in Fisheries Science, 18(1), 25-39.

Schofield, P.J. \& Nico, L.G. (2009). Salinity tolerance of non-native Asian swamp eels (Teleostei:
Synbranchidae) in Florida, USA: Comparison of three populations and implications for dispersal. Environmental Biology of Fishes, 85, 51-59.

Shoko, A.P., Limbu, S.M., Mrosso, H.D.J., Mkenda, A.F., \& Mgaya, Y.D. (2016). Effect of stocking density on growth, production and economic benefit of mixed sex nile tilapia (Oreochromis niloticus) and African sharptooth catfish (Clarias gariepinus) in polyculture and monoculture. Aquaculture Research, 47,36-50.

Soekartawi, Soeharjo, A., Dillon, J.L., \& Hardaker, J.B. (1986). Ilmu Usaha tani dan Penelitian untuk pengembangan petani kecil. Jakarta: Universitas Indonesia Press, $253 \mathrm{hlm}$.

Steel, R.G.D. \& Torrie, J.H. (1981). Principles and procedures of statistcs. A biometrical approach. McGraw Hill Kogakusha Ltd., 633 pp.

Tok, C.Y., Chew, S.F., Peh, W.Y.Z., Loong, A.M., Wong, W.P., \& Ip, Y.K. (2009). Glutamine accumulation and up-regulation of glutamine synthetase activity in the swamp eel, Monopterus albus (Zuiew), exposed to brackish water. The Journal of Experimental Biology, 212, 1248-1258.

Wedemeyer G.A. (1996). Physiology of fish in intensive culture systems. New York: Chapman $\&$ Hall, $232 \mathrm{pp}$.

Yuan, Y., Yuan, Y., Dai, Y., \& Gong, Y. (2017). Economic profitability of tilapia farming in China. Aquacultural International, 25, 1253-1264. 